\title{
Initial seismic observations from a deep borehole drilled into the Canadian Shield in northeast Alberta
}

\author{
Judith Chan · Douglas R. Schmitt
}

Received: 14 May 2014 / Accepted: 21 November 2014 / Published online: 5 December 2014

(C) The Author(s) 2014. This article is published with open access at Springerlink.com

\begin{abstract}
The availability of a deep borehole in northeastern Alberta provides an unprecedented opportunity to study the in situ metamorphic craton rocks. This borehole reaches a depth of $2.4 \mathrm{~km}$, with $1.8 \mathrm{~km}$ in the crystalline rocks, and is the only known borehole allowing access into the deeper rocks of the metamorphic Canadian Shield. In 2011, a zerooffset vertical seismic profile (VSP) was acquired to assist in the interpretation of seismic reflection data and geophysical logs. Three sets of upgoing tube waves interpreted from the raw profile correspond to the small-scale fluctuations in the borehole diameters and fracture zone in the crystalline rocks. A comparison between sonic log velocities and VSP velocities reveals a zone with increased velocity that could be due to the change in rock composition and texture in the basement rocks. The final processed profile is used to generate corridor stacks for differentiating between primary reflections and multiples in the seismic reflection profile. Analysis of the zero-offset VSP verifies existing log interpretation on the presence of fractures and the possible lithological changes in the metamorphic rocks of the Canadian Shield.
\end{abstract}

Keywords Zero-offset VSP · Canadian Shield · Craton rocks $\cdot$ Metamorphic rocks · Velocity seismic profiling · Tube waves

J. Chan $(\varangle) \cdot$ D. R. Schmitt

Department of Physics, Institute for Geophysical Research,

University of Alberta, 4-181 CCIS, Edmonton, AB T6G 2E1,

Canada

e-mail: judithc@ualberta.ca

D. R. Schmitt

e-mail: dschmitt@ualberta.ca

\section{Introduction}

Active-source seismic reflection profiling has played key roles in helping to shape our concepts of the structure and assembly of the earth's continental cratonic crust since the discovery in the 1960 s that reflections returning from it can be detected (e.g., Kanasewich and Cumming 1965). Without 'ground truthing' through drilling, however, the interpretations of such profiles remain speculative, and even though these reflections may lie only a few kilometers beneath the surface, interpretations become 'certain' according to Birch's (1952) definitions, much like studies of the less accessible earth's mantle. Ultimately returning events signal variations in density and seismic wave speeds over relatively small distances relative to the seismic wavelength are related to changes in lithology or mechanical properties (i.e., fracturing). The only way to truly know this is to directly sample the earth by drilling; it is important to take advantage of any opportunities that may arise to learn more about the sources of seismic reflectivity in such crystalline crust.

To our knowledge, there are no statistics on the number of boreholes drilled globally into the metamorphic crystalline cratons. With the vast mineral deposits they hold, it would not be surprising if this figure reached into the many hundreds of thousands or even more. Understandably, their locales are biased to economically important sites, but even so there is regrettably little public information available for more detailed scientific investigations. Despite this, there have been a small number of boreholes drilled for scientific research purposes such as the KTB pilot 'Vorborhrung' and the 9,101-m main 'Hauptborhrung,' Germany (Emmermann and Wohlenberg 1989; Emmermann and Lauterjung 1997), the 2,500-m Outokumpu Deep Drilling Project, Finland (Kukkonen 2011), and the 5,158-m Donghai borehole, 
China (Ji and Xu 2009; Luo and Pan 2010). At this writing, the Collisional Orogeny in the Scandinavian Caledonides (COSC) project in Sweden (Lorenz et al. 2011) has completed the first of its two 2,500-m-deep boreholes. Many of these drilling projects are associated with the International Continental Drilling Program (ICDP). There are also a limited number of borehole investigations in Western Canada that take advantage of mineral exploration programs (e.g., Drury 1985; Mwenifumbo et al. 2004).

Active seismic investigations, more commonly referred to as vertical seismic profiles (VSP) within such wells are rarer still, but have been important in helping us to decipher what the source of crustal reflections are. Detailed borehole seismic surveys have been carried out at Kola (Pavlenkova 1992; Carr et al. 1996; Ganchin et al. 1998), KTB (Li and Richwalski 1996; Lüschen et al. 1996; Harjes et al. 1997; Okaya 2004; Rabbel et al. 2004), and Outokumpu (Duo 2011; Heinonen et al. 2011; Kukkonen et al. 2012; Schijns et al. 2012). Surveys in similar crystalline lithologies but in more tectonically active zones include studies at Soultzsous-Forêts, France (Place et al. 2011), and Cajon Pass, California (Rector 1988), for mineral exploration (e.g., Miao et al. 1994; Eaton et al. 1996), and for repository characterization (e.g., Cosma et al. 2001).

Outside of the crystalline rock masses, VSP studies have been used to assist with geothermal development. At the Larderello geothermal field in central Italy, Cameli et al. (1995) analyzed VSP data with other geological and geophysical information to help identify important seismic reflectors inside the metamorphic basement. These subhorizontal reflectors were found to correlate with a producing fracture zone that intersected a borehole in the geothermal reservoir. At the Kakkonda geothermal reservoir in Japan, VSP imaging shows an up-dip pattern, which was associated with the slope of an anticline. This interpretation was used to constrain the positioning of seismic reflectors deduced from the poor quality seismic reflection survey and revealed geological structures that were not previously apparent in the seismic data (Nakagome et al. 1998). At the Rye Patch geothermal field in Nevada, Gritto et al. (2003) used multiple VSP surveys to obtain information on the velocity structure and the reflectivity of the subsurface. The goal was to explore the structural features that may control geothermal production in the area. Based on the changes in velocity and strong seismic reflectivity, it was suggested that localized geological heterogeneity is present in the area as a result of hydrothermal alteration and volcanic deposition. Despite the uncertainty in the identification and mapping of faults in this area, the VSP surveys indicated the existence of at least one fault which led to further investigation of the field using a 3D seismic reflection survey.

The physical properties of metamorphic rocks in Alberta beneath the Western Canada sedimentary basin (WCSB)

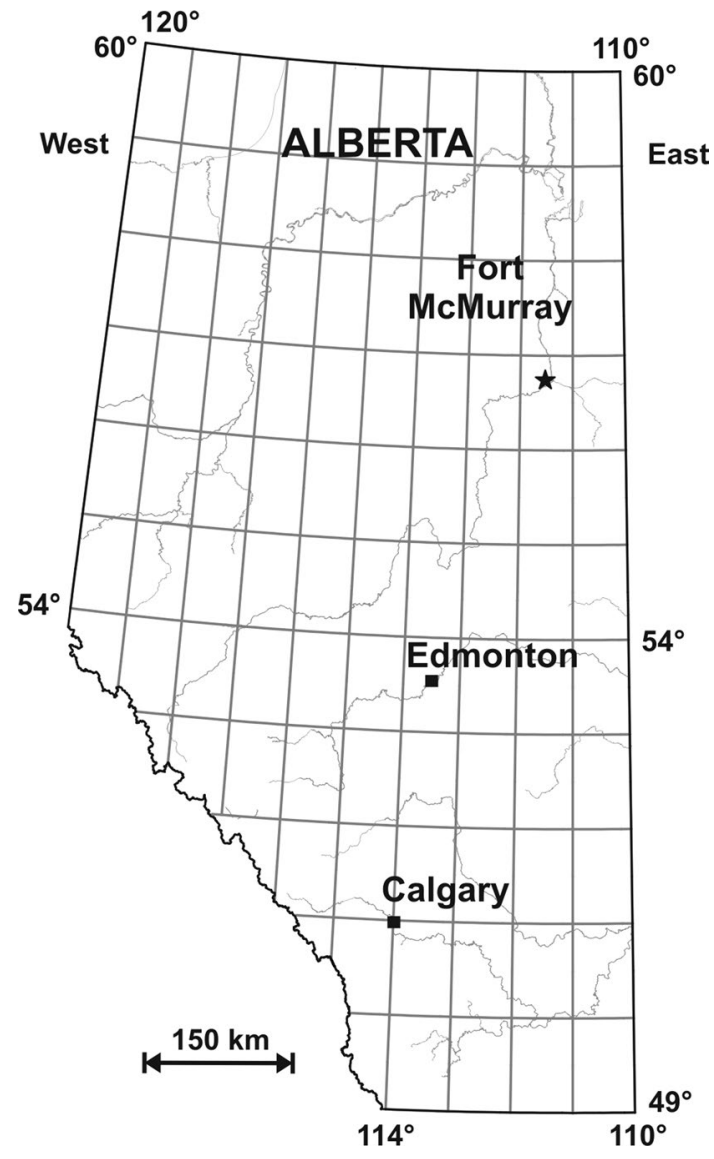

Fig. 1 The study borehole is located in the western suburb of Fort McMurray, as marked by a star on the Alberta map

are poorly understood since subsurface studies in the province have primarily been driven by the petroleum industry with a central focus on the sedimentary layers (Bartetzko et al. 2005). That said, over 4,000 exploratory boreholes have penetrated the metamorphic Precambrian basement in Western Canada, but coring and logging into the basement rocks are almost exclusively limited to the sedimentary successions (Pană 2003). The boreholes that do cross the Precambrian unconformity penetrate at most a few meters into the basement. While the cores and cutting materials obtained from these boreholes have provided key information in developing the age and radioactivity of the rocks, there is insufficient core or log information on the geophysically important properties of the basement (Burwash and Culbert 1976; Burwash and Cumming 1976; Burwash 1979; Drury 1988). This lack of access has limited scientific studies of the craton to the few short core samples and to remote mapping of Proterozoic tectonic terranes using magnetic surveys.

Recently, as part of the regional geothermal resource investigations, we have been able to access a rare 2,363-m-deep borehole drilled in stages between 1994 and 
2003 into the metamorphic rocks in Alberta at $56^{\circ} 45^{\prime} \mathrm{N}$, $111^{\circ} 33^{\prime} \mathrm{W}$ (Fig. 1). This well was drilled for commercial exploration in stages between 1994 and 2003, and hereafter, we refer to it as the Hunt well. This borehole first penetrated $541 \mathrm{~m}$ of sedimentary successions followed by 1,822 m of metamorphic rock units. From 1,006 m down to the bottom of the borehole, it is directly exposed (i.e., open hole) to the hard, crystalline Canadian Shield (Fig. 2). As such, this borehole provides an unrivaled opportunity to study the in situ conditions within the Canadian Shield underlying the Western Canada sedimentary basin (WCSB). An extensive series of logs and borehole seismic data has been collected during the initial drilling phases and more recently by teams at the GeoForschungZentrum-Potsdam and the University of Alberta (Chan 2013). Majorowicz et al. (2014) have recently reported on the geothermal gradients and heat flow from parallel field programs. Here, we present a preliminary analysis of the zero-offset VSP data set. In the following, we describe the regional geological setting, the components of the field acquisition and data processing, and the interpretation of these results.

\section{Geological overview}

To date, study of the Canadian Shield has been investigated mainly on the surface through geological and geophysical field mapping (e.g., Langenberg and Nielsen 1982; Goff et al. 1986; Burwash et al. 1994, 2000; McDonough et al. 2000). The exposed Canadian Shield in the northeastern part of Alberta allows for direct mapping of the Proterozoic metamorphic rocks where the exposed geology can be traced unambiguously into the subsurface using magnetic mapping (Ross 2000). The complex metamorphic rock assemblages of the Canadian Shield rocks dip gently toward the southwest at 4-5 m per kilometer and are overlain by the Paleozoic passive margin and WCSB. The Shield beneath the borehole consists of massive to foliated granitoids, banded granite gneisses, and layered to banded metasediments (Langenberg and Nielsen 1982). In the Hunt well, a rock sample at 2,350 m is identified as foliated meta-granite composed mostly of quartz and feldspars (Walsh 2013; G. Njiekak, personal communication, January 23, 2014; Chan and Schmitt 2014). The uppermost $541 \mathrm{~m}$ of the geological column consists of Paleozoic and Cretaceous sediments which are well sealed behind three different steel casings (Fig. 2).

The Precambrian crystalline basement is commonly hypothesized to have been reactivated during the Phanerozoic eon (541 Ma to present), which may explain the long, linear, or anomalous trends of the sedimentary deposits. As a result of the Proterozoic orogenic activity from more than $1.8 \mathrm{Ga}$, faults and shear zones formed at the time have been

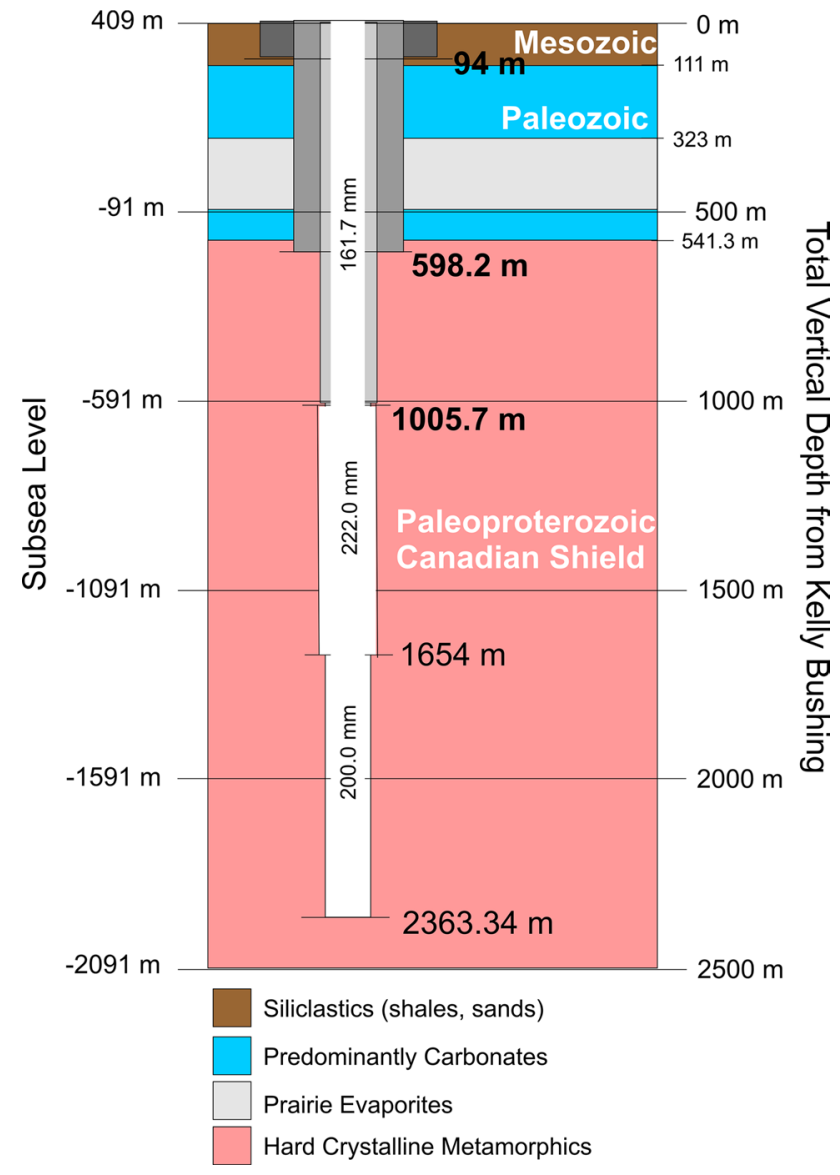

Fig. 2 Schematics of the deep borehole located west of Fort McMurray, Alberta, Canada. This borehole penetrates $541 \mathrm{~m}$ of the sedimentary successions and 1,822 $\mathrm{m}$ of the metamorphic Canadian Shield. The steel casings are set at 94 and $598 \mathrm{~m}$ with a change in borehole diameters at 2 different depths

interpreted in the shallow seismic profiles that offset the Phanerozoic section (Ross and Eaton 1999). Understanding the metamorphic basement rocks beneath the WCSB in Alberta is accomplished by interpreting the crustal seismic data and potential field maps (e.g., Ross et al. 1991; Pilkington et al. 2000; Lyatsky and Pană 2003). According to these magnetic-based interpretations, the borehole lies in the Taltson Magmatic Zone, a region believed to have been produced subduction-related plutonism (Ross 2002).

\section{Seismic reflection profile}

A number of deep seismic reflection profiles were obtained over the craton in Western Canada in the 1990s as part of the LITHOPROBE Alberta and TransHudson Orogen transects (Clowes 2010). These programs collected deep seismic profiles to the east, south, and west of the borehole (e.g., Hope et al. 1999; Bouzidi et al. 2002; Hajnal et al. 
Fig. 3 a The location of the study borehole (Hunt well) and 2D seismic surveys in the dominion land survey (DLS) system of Alberta west of the 4th Meridian. The 1993 crooked 2D seismic survey has a profile length of $24 \mathrm{~km}$, whereas the 2011 straight seismic survey (not discussed in this paper, Chan 2013) is $3 \mathrm{~km}$ long. Both profiles are (re-)processed to allow proper imaging of the upper crust near the borehole. b The reprocessed stacked section of the older 2D seismic profile reveals a series of dipping reflectors in the Precambrian basement. The projected location of the borehole is indicated by the black arrow with a bottom hole depth of 2,363 m. Two of the dipping reflectors $(1,450$ and $2,750 \mathrm{~m}$ ) are indicated by the black dashed lines. $\mathbf{c} \mathrm{A}$ zoom-in section of $\mathbf{b}$ (red box) shows clear dipping reflectors in the basement rocks as indicated by the blue arrows

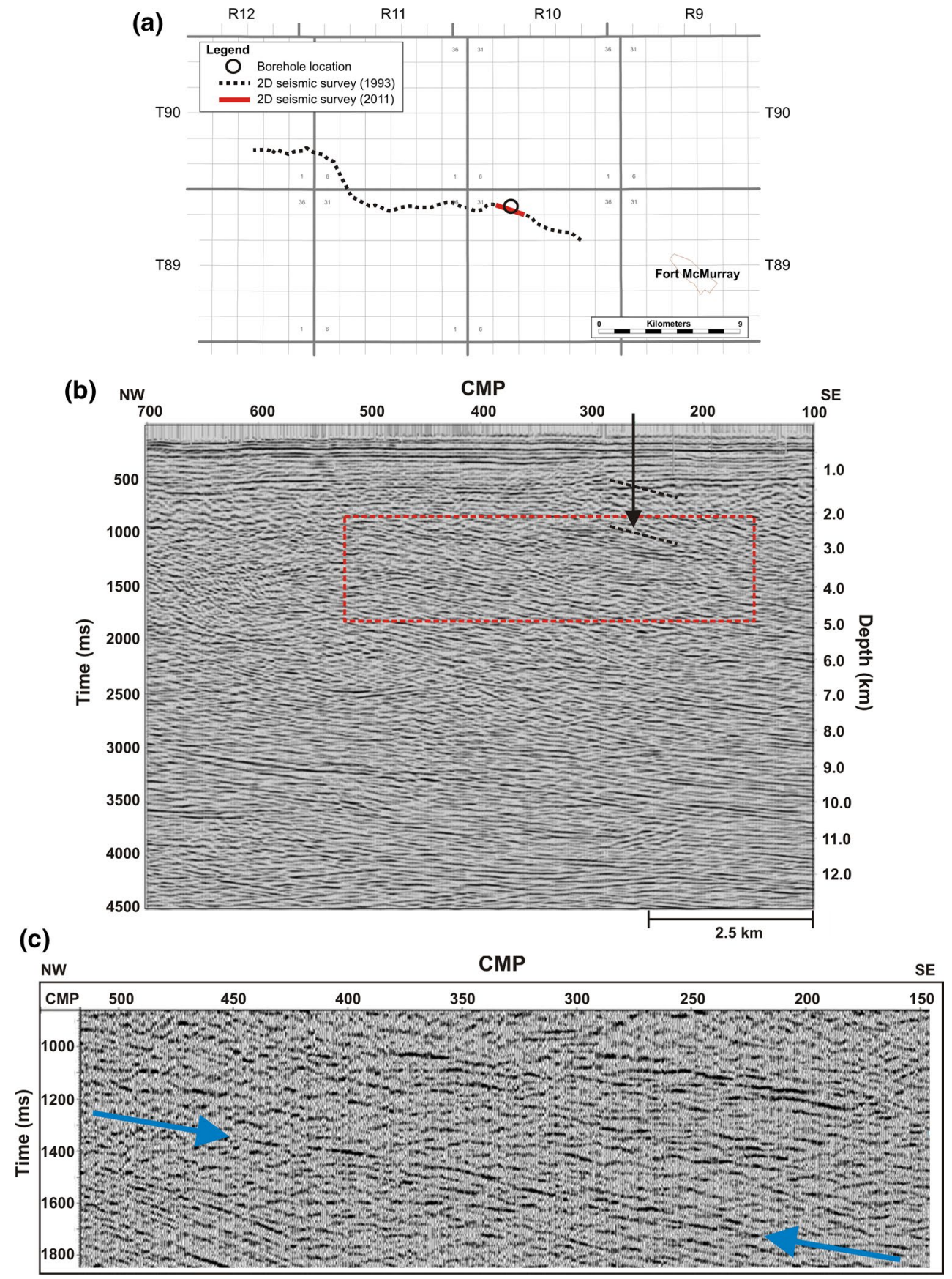

2005). The closest of these still lies more than $500 \mathrm{~km}$ away from the Hunt well and none of them cross the Taltson Magmatic Zone.

Fortunately, part of the original site selection activities for the well included a deep 2D seismic survey with 12-s two-way travel times. This survey was acquired in 1993 at about $165 \mathrm{~m}$ south of the borehole (Fig. 3a) along the only existing continuous road nearby. This crooked profile is $24 \mathrm{~km}$ long and was designed to have a far receiver offset of $6.3 \mathrm{~km}$ to allow for deep subsurface imaging of approximately $35 \mathrm{~km}$ into the crystalline basement rocks.
Details of the acquisition parameters can be found in Chan (2013).

This profile reveals numerous gentle to steeply eastdipping reflectors in the Precambrian basement (Fig. 3b, c). Due to the crookedness of the seismic profile, energy from out of plane can degrade the overall stacked image, and reflections in the shot gathers may also not be properly imaged. Some of the observed reflections in the profile are also possibly out-of-plane reflections (side-swipes) that could indicate more complex 3D structure. As the profile is somewhat crooked, normal incidence data may 
not represent a vertical plane and may contain geological information from out-of-plane sections. Multiple reflections produced within the overlying sediments are also often a problem in deep seismic profiles over sedimentary basins (e.g., Bouzidi et al. 2002). To overcome some of these deficiencies, reprocessing of this profile focused on both the multiples and near-surface noise attenuation to improve the temporal resolution of the stacked seismic sections. This included implementation of frequencywavenumber filtering, radial trace transform, predictive deconvolution, and time-variant filtering techniques. The section was migrated using finite difference migration. Further details of this reprocessing sequence are again found in Chan (2013).

The final stacked and migrated seismic surveys reveal eastward-dipping reflectors in the crystalline basement at $960,1,450$, and $2,750 \mathrm{~m}$ depth (Chan 2013). With the study borehole at a maximum depth of $2,363 \mathrm{~m}$, the reflectors at 960 and $1,450 \mathrm{~m}$ might intersect the borehole at an offset of $165 \mathrm{~m}$. Such dipping reflectors could be related to structural features, such as faults and/or fracture zones that could play significant roles in improved permeability toward the development of engineered geothermal systems in the Precambrian basement rocks. This motivates us to investigate the origin of these reflectors by acquiring a zero-offset VSP in the Hunt well.

\section{Vertical seismic profiling}

Surface seismic surveys offer substantial coverage of the subsurface when no existing boreholes are available in the study area. However, the complex structures of fractured reservoirs in the crystalline basement cannot always be properly resolved at the reservoir scale (e.g., Schutter 2003; Luthi 2005; Al-Ali et al. 2009; Place et al. 2011). Consequently, borehole geophysical surveys such as the vertical seismic profiling are utilized to minimize the ambiguity in the interpretation of seismic reflection surveys.

VSP is a measurement in which the seismic source is generated at the surface, and seismic signal is recorded by geophones secured at various depth levels to the borehole wall (e.g., Hardage 2000) (Fig. 4). By placing the geophones directly into the borehole versus surfaceplanted geophones in a seismic survey, and also its higher frequency content, VSP imaging overcomes hurdles of seismic attenuation and reveals reflectors that could not always be resolved by surface seismic data. These reflectors have proven to associate with dipping geological structures and flow anomalies that affect the development of a geothermal reservoir (e.g., Nakagome et al. 1998; Melosh et al. 2010; Place et al. 2011). This form

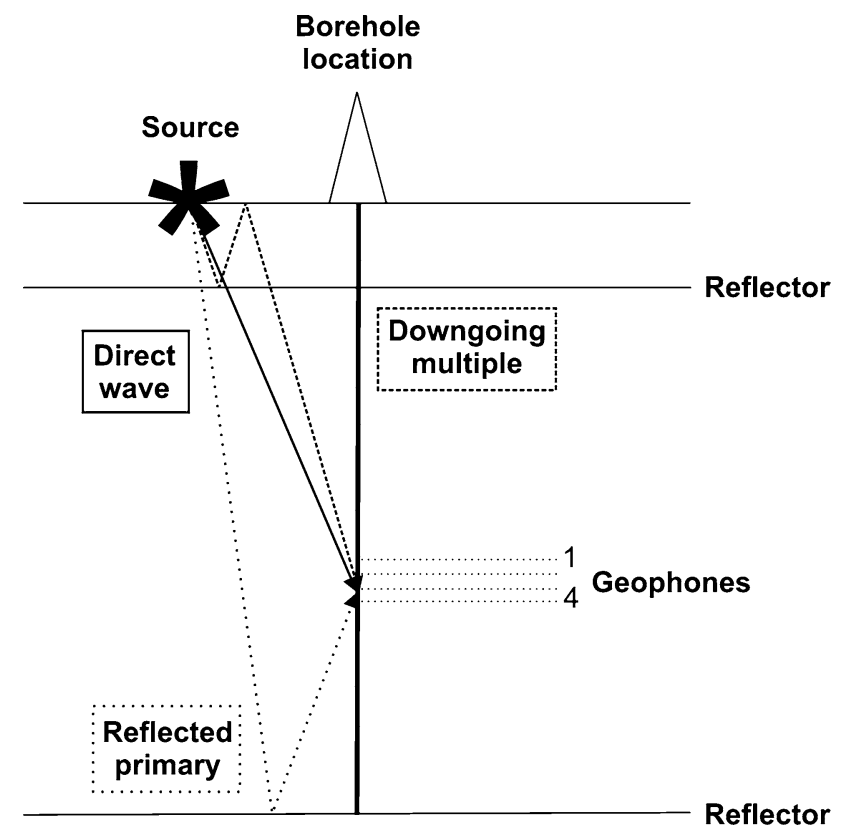

Fig. 4 The operation of a vertical seismic profile survey consists of a chain of geophones lowered into the borehole and a surface seismic energy source emitting acoustic energy. Upgoing and downgoing waves are detected by the geophones, and data are transmitted through the wireline back to the data recorder on the surface

of borehole geophysics provides in situ measurements of rock properties including velocity, acoustic impedance, attenuation, and anisotropy (Stewart 2001). Since the geophones are placed directly in the borehole, VSP has better seismic resolution compared to surface seismic profiles since the data quality is less likely to be compromised by the effect of surface layers. Frequency content of the VSP encounters less attenuation effects in the one-way travel path versus the two-way travel path in seismic reflection profiles. The one-way travel path from source to receivers leads to an enhanced image of the reflectors in the subsurface after a proper processing routine is applied. The recorded travel time and known depth level of the receivers provide the interval velocities necessary in deriving a time to depth relationship of the recorded seismic data. However, this is also restricted to the area between the seismic source and borehole location (Schmitt et al. 2007). Seismic energy sources positioned within tens of meters of the borehole are considered to be a zero-offset VSP (Stewart 2001).

Many important reflectors detected by several VSPs recorded in the metamorphic basement could be attributed to the change in petrophysical characteristics of the rocks, particularly changes in fracture density, rather than contrasts in lithology (Cameli et al. 1995). Interval velocities extracted from the VSP data are useful in determining the variation of seismic velocity with depth with possible 
Table 1 Acquisition parameters of the zero-offset vertical seismic profile a Owned by the Operational Support Group of International Continental Scientific Drilling Program (ICDP-OSG)

\begin{tabular}{ll}
\hline Parameter & Zero-offset VSP \\
\hline Year of acquisition & 2011 \\
Source type & $6000-$ lb IVI Minivib ${ }^{\mathrm{TM}}$ \\
Source elevation & $404.3 \mathrm{~m}$ \\
Sweep frequencies & $10-160 \mathrm{~Hz}$ linear \\
Offset distance & $27 \mathrm{~m}$ \\
Receiver type & Sercel's SlimWave ${ }^{\mathrm{TM}}$ borehole geophone chain $^{\mathrm{a}}$ \\
& 2 horizontal and 1 vertical 15 Hz geophones \\
Geophone spacing & $10 \mathrm{~m}$ \\
Number of 3C geophones sondes & 4 \\
Top measured depth (relative to KB) & $5 \mathrm{~m}$ \\
Bottom measured depth (relative to KB) & $1,880 \mathrm{~m}$ \\
Number of measured levels & 186 \\
Sampling depth interval & $2.5 \mathrm{~m}$ \\
Correlated record length & $5 \mathrm{~s}$ \\
Sample rate & $0.5 \mathrm{~ms}$ \\
\hline
\end{tabular}

geological significance. Besides using the VSP data for reflectivity and velocity analysis, they can be interpreted separately for fracture analysis and toward an understanding of the degree of seismic anisotropy in the rock mass (e.g., Schijns et al. 2012). Such information is useful for the development of a geothermal reservoir and provides input parameters for the fracturing and reservoir simulation of a geothermal system.

Field acquisition

A zero-offset VSP acquisition operation was carried out in July 2011 with the acquisition parameters listed in Table 1. Using a high-frequency Minivib ${ }^{\mathrm{TM}}$ unit (Industrial Vehicles International of Tulsa, Oklahoma) as the seismic energy source, data were recorded upward from 1,880 to $5 \mathrm{~m}$ depth with 4 levels of receivers spaced $10 \mathrm{~m}$ apart, at $2.5 \mathrm{~m}$ intervals. The source employed $13 \mathrm{~s}$ linear taper sweeps with frequencies at $10-160 \mathrm{~Hz}$ and was positioned at an approximate $27 \mathrm{~m}$ offset from the borehole. Each shot was repeated for the later digital summation of shots at common depths to increase the signal-to-noise ratio of the traces. The three-component receivers used were part of the Sercel's SlimWave ${ }^{T M}$ borehole geophone chain owned by the operational support group of International Continental Scientific Drilling Program (ICDP-OSG). Conventional VSPs are typically acquired at relatively large intervals of $10 \mathrm{~m}$ or more primarily of economic cost and the acquisition time required. In this borehole, a frequent depth sampling of $2.5 \mathrm{~m}$ was carried out to obtain greater spatial depth resolution on the in situ seismic velocities (Schmitt et al. 2007). Waveforms were recorded as functions of time and plotted against depth to produce the vertical profile (Fig. 5).

\section{Data processing}

The positioning of receivers in the borehole allows them to record both downgoing and upgoing wave fields directly. Downgoing wave fields are dominant in the unprocessed VSP such that it becomes difficult to interpret the upgoing primary reflections (Fig. 5). Furthermore, random noise and coherent noise in the raw data need to be attenuated to improve the signal-to-noise ratio prior to interpretation. A typical VSP processing routine comprises of geometry assignment, trace editing, noise attenuation, first arrivals time picking, velocity analysis, wavefield separation, and corridor stack generation (Table 2). In this study, only the vertical component of the zero-offset VSP was processed, given that the short offset from the borehole attempts at rotation of all three geophone components did not improve the data quality. The VISTA ${ }^{\text {TM }}$ Seismic Data Processing software package provided by GEDCO was used with details on the processing routine found in Chan (2013). The strongest amplitude arrival is the 'downgoing' wave that arrives directly to the receivers from the surface source (Fig. 5). Such events are so dominant that the primary upgoing reflections particularly in the sedimentary layers are hardly visible in the VSP section. The first arrival downgoing events are used to develop a detailed velocity profile for the borehole with data points at every $2.5 \mathrm{~m}$ from 1,880 to $5 \mathrm{~m}$.

To separate the upgoing and downgoing events from the seismic data, various numerical procedures can be applied to attenuate the downgoing modes without seriously affecting the upgoing events (Hardage 2000). The median filter technique was used for separation of the upgoing from the downgoing wave fields. It is considered as a data smoothing filter by selecting the median value of an ascending-ordered 
Fig. 5 Observed zero-offset vertical seismic profile after post-acquisition stacking of common depth traces and application of an automatic gain control function. This display is generated prior to data processing, and thus, it includes both upgoing and downgoing events. The quality of the seismic traces are poorer in the open hole section below $1,006 \mathrm{~m}$ as the rugosity of the borehole prevents the stable coupling of the geophone chain to the borehole wall

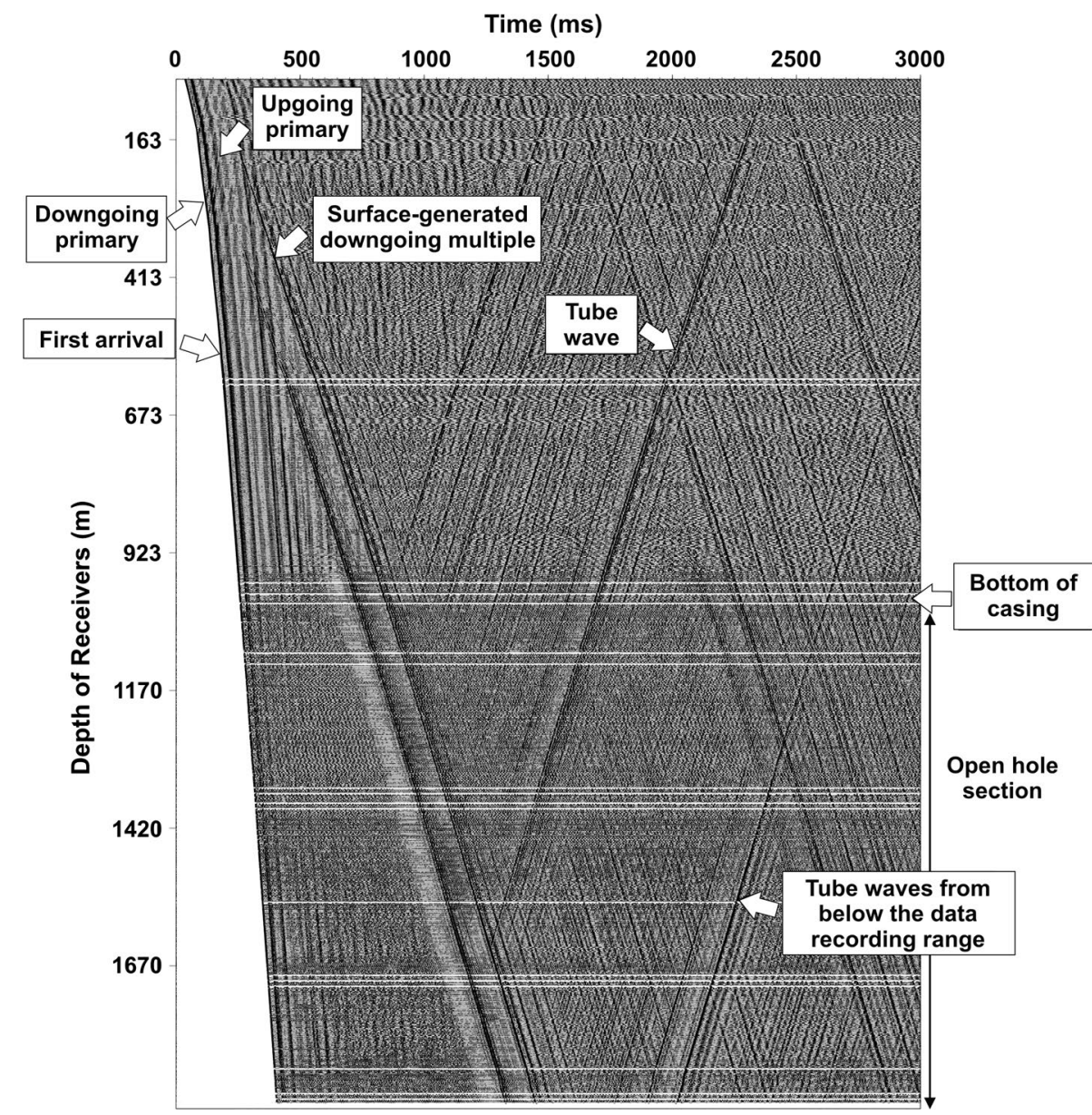

Table 2 Processing sequence for the zero-offset vertical seismic profile

\begin{tabular}{ll}
\hline Processing step & Justification \\
\hline Geometry setup and trace editing & Prepare data for processing and eliminate bad traces \\
Vibroseis correlation & Correlate vibroseis trace with the sweep wave train \\
Stacking at constant recording depth & Increase signal-to-noise ratio with repeated recordings at common depth \\
Component separation & Separate $X, Y, Z$ component \\
First arrival picking & Calculate interval velocity and generate time-depth relationship \\
Gain correction & Compensate for energy losses \\
FK filtering & Minimize the effect of tube waves \\
Median filtering & Separate and enhance the downgoing and upgoing wavefields \\
Deconvolution & Remove multiples from the upgoing wavefield \\
Corridor stack & Apply vertical summation to yield a single stacking trace emphasizing upgoing events
\end{tabular}

sequence of numbers from a moving window of input data (Stewart 1985; Hardage 2000). Two major advantages of using this type of filter are its ability to reject noise spikes and to pass step functions (i.e., discontinuities in the data) without smearing the edges. One important note in the wavefield subtraction process is that first-break times must be interpreted carefully to minimize any static time shift error in the wavefield separation (Stewart 1985; Hardage 2000).
Since geophones are placed in the subsurface in a VSP survey, they record the initial downgoing source signature pulse and its upgoing primary reflections as modulated by attenuation and made more complex by later multiple reflections. The small design window used in deconvolution helps to minimize any noise contamination in the design filter. This is followed by a static time shift according to the first-break arrivals to convert the one-way travel 


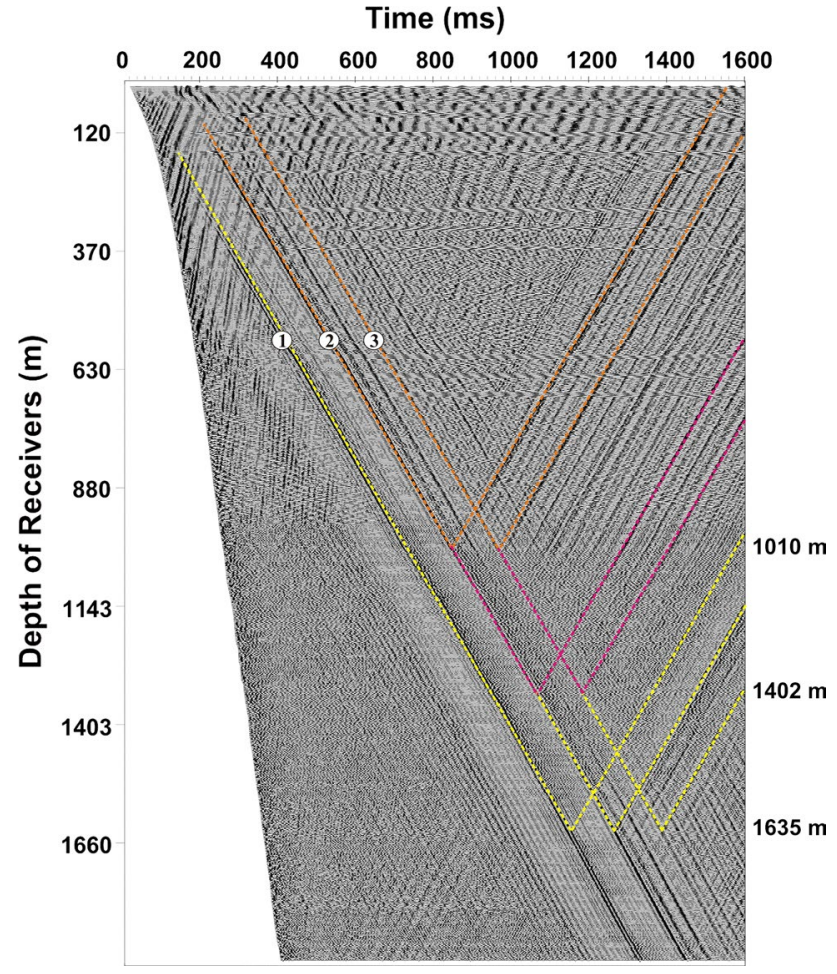

Fig. 6 Outlines of downgoing, upgoing primary, and multiple tube waves in the zero-offset vertical seismic profile. Three different sets of downgoing and upgoing waves are identified by \#1 (1,010 m), \#2 $(1,402 \mathrm{~m})$, and \#3 $(1,635 \mathrm{~m})$. \#1 and \#3 correspond to the change in borehole diameter, whereas \#2 corresponds to a known fracture zone that was previously interpreted from the geophysical logs

time of the VSP into a two-way travel time for comparison between borehole seismic and seismic reflection profiles. This also allows us to accurately identify the depth of reflectors as seen in Fig. 6.

The seismic traces are noisy below $1,006 \mathrm{~m}$ in the open hole environment. Borehole rugosity, as indicated by the caliper $\log$ at 1,140-1,405 $\mathrm{m}$ depth (Fig. 7), affects the clamping of the geophone to the formation which resulted in weaker recorded signals (Fig. 6). Another problem is that the arms of the tool were too short and could not be properly locked in place in the open hole section.

\section{Results}

A processing workflow was applied to the zero-offset VSP to assist in the interpretation of seismic reflection data and borehole $\operatorname{logs}$ as outlined in Table 2. Data analysis was performed carefully on the vertical component of the borehole seismic data to obtain a proper velocity profile for seismic processing and toward understanding the origin of tube waves. Because of the problems with sonde coupling in parts of the borehole, the interpretation of the reflectors in

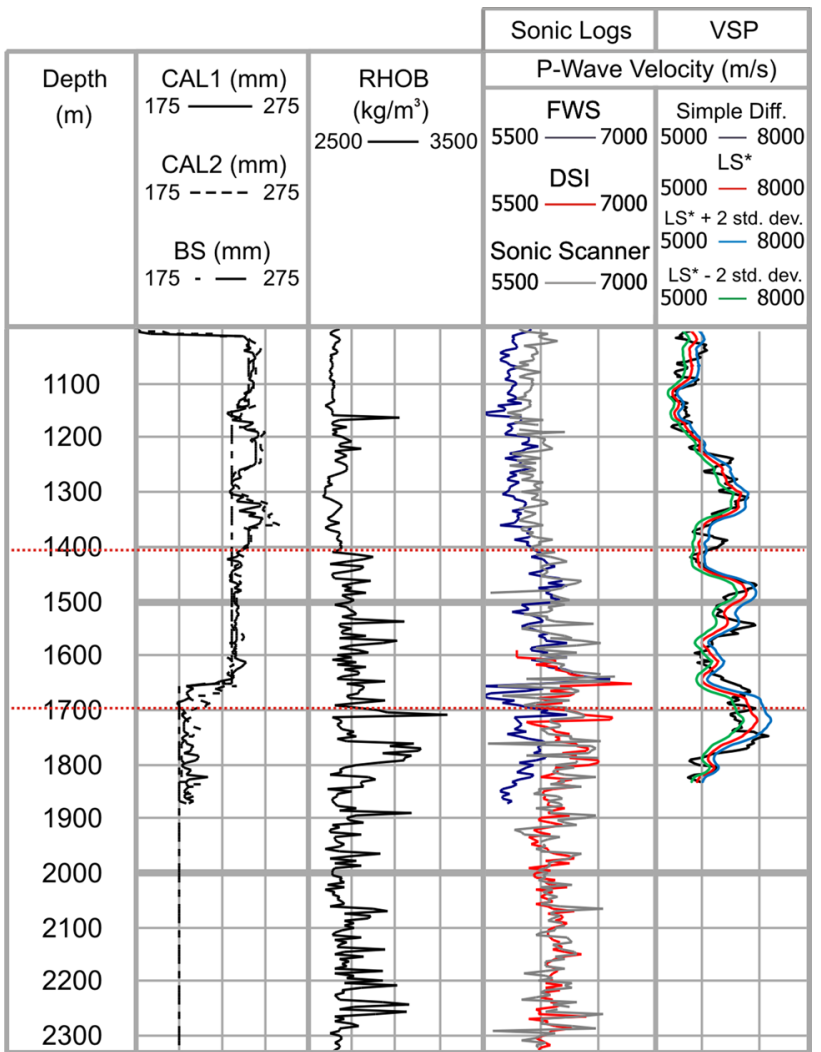

Fig. 7 Velocity profiles from the zero-offset VSP and different sonic logging tools through the open hole section. Interval velocities from the VSP data are calculated by dividing the depth difference by the time difference at the top and bottom of 50 samples $(122.5 \mathrm{~m})$, followed by calculating the velocity from the linear slope (LS*) fit of all times over window with the $95 \%$ confidence intervals. The upper and lower boundaries (red dashed lines) contain the zone with strong impedance contrasts as identified by the strong reflectors in the corridor stacks

the lower section of the borehole is supported by the synthetic seismograms generated using the sonic logs.

\section{Velocity profile}

First-break times were carefully and manually picked on the vertical component traces since automated time picking becomes more complicated with the presence of random noise. Amplitude noise results in smeared first arrivals that affect the accuracy of travel time determination. The zerocrossing point from trough to peak was used as the selection criterion for the first-break picking. In situ interval velocities were determined from the travel times and plotted in Fig. 7 for comparison with other sonic log measurements, including full-waveform sonic (FWS), dipole shear sonic imager ${ }^{\mathrm{TM}}$ (DSI), and sonic scanner ${ }^{\mathrm{TM}}$ logs.

Sonic logging provides measurements of interval velocities at higher frequencies (approximately $20 \mathrm{kHz}$ ) and 

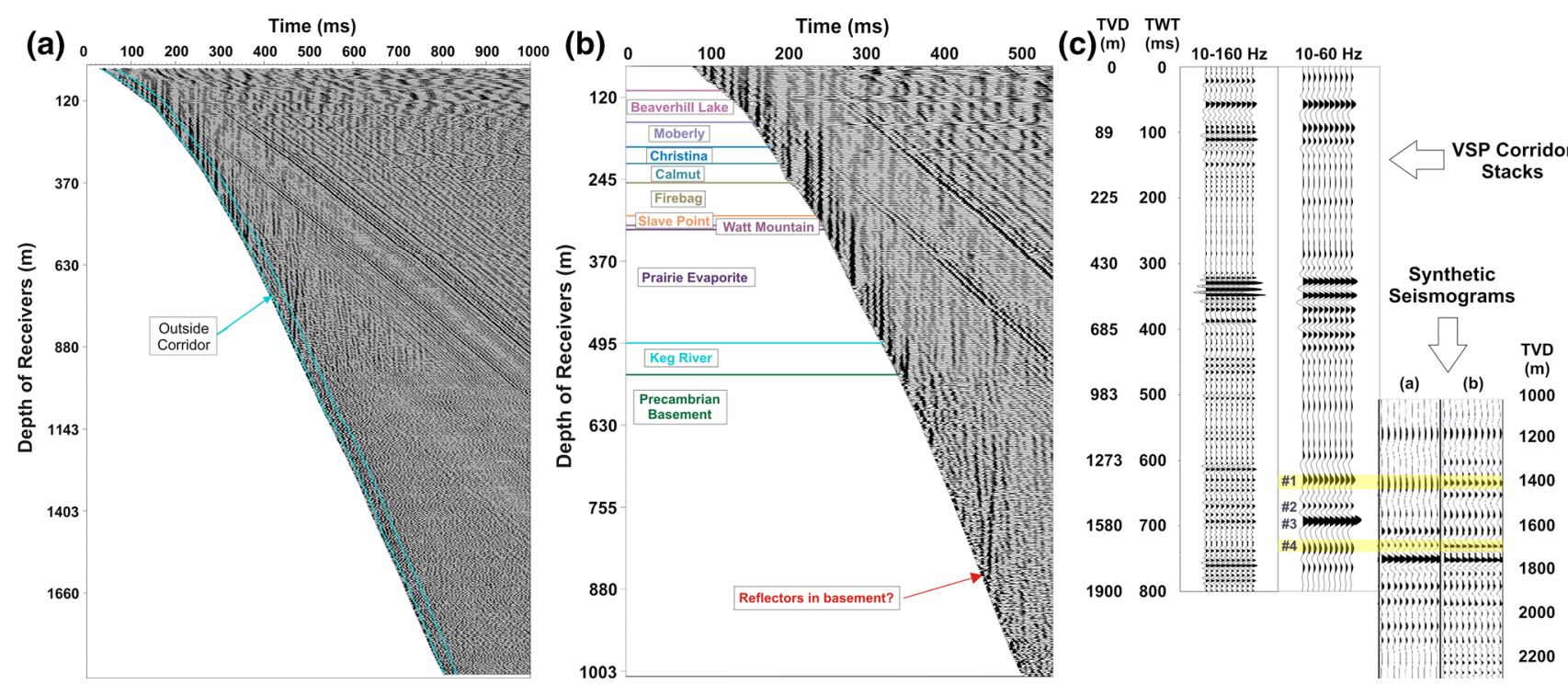

Fig. 8 a Upgoing seismic events become more apparent after data processing. A $25 \mathrm{~ms}$ outside corridor was selected to generate the final corridor stacks in (b). b Upgoing waves after deconvolution. The zero-offset VSP data in the cased hole section are flattened and displayed in two-way travel time. Seismic reflectors are more apparent in the upper $541 \mathrm{~m}$ in the sedimentary successions. A strong event observed at $\sim 880 \mathrm{~m}$ suggests the existence of reflectivity in the crys- talline Canadian Shield. c Comparison between VSP outside corridor stacks and synthetic seismograms generated from velocity and density logs. Synthetic seismograms are generated using the velocity profiles from the sonic scanner at $a 10-60 \mathrm{~Hz}$ and $b 10-160 \mathrm{~Hz}$. Events $\# 1(1,408 \mathrm{~m})$ and \#4 $(1,695 \mathrm{~m})$ are considered as primary reflections as they are present in both data types. Events \#2 and \#3 are questionable

explanation for this observation is the change in rock composition and texture in the basement rocks (Vernik et al. 1994). Unfortunately, with the limited cores available in this deep borehole, it is difficult to understand the exact causes of the localized increases in velocity and density in the basement. The increase near 1,760 m depth can be correlated with the potential mafic dyke that was previously interpreted in Chan (2013).

\section{Corridor stack and synthetic seismogram}

A corridor stack is a vertical summation procedure that sums the set of time-shifted traces to yield a single trace containing all upgoing events (Hardage 2000; Sheriff 2002). Only those amplitudes contained within a time window, ideally selected to exclude any primary multiple reverberations, are included. Vertical (i.e., constant time) summation is performed on the outside corridor data window (Hardage 1985) (Fig. 8a). This outside corridor window contains data beginning from a slight delay of the firstbreak time, and processors select the end time with equal time lines at each trace. This time window ideally contains only primary reflections because any interbed multiples delayed by a longer time will not be included (Burton and Lines 1996). This is also based on the assumption that the reflectors are flat and horizontal. Once this stacked trace is calculated, it is typically plotted repeatedly in the same track for display purposes. files extracted from the borehole sonic logs. A possible 
It is interesting to note some of the behaviors of the upgoing reflections in Fig. 8a. The strong events within the sedimentary column are easily seen and abruptly terminate as expected at its bottom near $541 \mathrm{~m}$. The seismic events in the sedimentary section are all associated with known geological contacts (Fig. 8b) as determined by Chan (2013). One strong event originating at $\sim 880 \mathrm{~m}$ depth is clearly seen as an upgoing reflection within the metamorphic column. This event is not horizontal suggesting that it is produced by a dipping reflector, and indicates the existence of reflectivity in the crystalline Canadian Shield. However, the lack of log information in this zone precludes a complete determination of the source of this event.

Here, the times of the corridor stack through the open hole section are of poorer fidelity than the upper cased section of the borehole. Using the corridor stacks to differentiate between primary reflections and multiples is questionable, but they are still useful in the interpretation of horizons in the overlying Phanerozoic sediments. The successions are in the upper $300 \mathrm{~ms}$ of the corridor stack data in which the borehole contains the steel casing and thus provides better geophone coupling. Borehole rugosity, as indicated by the caliper log, affects the clamping of the geophone to the formation which resulted in weaker recorded signals. Another problem was due to the insufficient length of the tool arms to lock the tool in place in the wide open hole section. As such, it poses a challenge to differentiate primaries and multiples from the VSP data set in the corridor stacks. To mitigate this, synthetic seismograms are generated from the sonic logs and employed to compare the reflectors with the VSP corridor stacks.

Density and sonic logs are first used to calculate a set of reflection coefficients (RC), which are then frequency-filtered to match the bandwidth of the seismic data. A seismic wavelet is the response of the seismic system and is defined by estimating the pulse from the real seismic data or using a standard pulse with a defined polarity, peak frequency, and phase. This seismic wavelet is used to convolve with the $\mathrm{RC}$ in time to generate the final synthetic seismogram. For this study borehole, the sonic log was extracted from the sonic scanner ${ }^{\mathrm{TM}}$ data set acquired in 2013 in the open hole section of the borehole (1,006-2,320 m). The reflection coefficient is convolved with wavelets extracted from the $2 \mathrm{D}$ seismic reflection survey discussed in Sect. 3 and generated with two different frequency ranges (10-160 and 10-60 Hz) close to those of the available seismic data sets (Chan 2013).

Comparisons between the corridor stacks from the VSP data and synthetic seismograms from the sonic logs are illustrated in Fig. 8c. The goal of this process is to identify the true reflectors and artifacts in the corridor stacks using the synthetic seismograms. This process focuses on the depth ranges between 1,006 and 1,800 $\mathrm{m}$ where there is reasonable overlapping of data between the VSP and sonic log. Four identifiable reflectors (\#1-\#4) in the VSP corridor stacks are labeled in Fig. 8c. Events \#1 (1,408 m) and \#4 $(1,695 \mathrm{~m})$ are identifiable in both data sets, which indicate changes in acoustic impedance at those depths.

As observed in the velocity profiles in Fig. 7, large velocity variations are subjected to the minor fluctuations in the first-break picks of the VSP data. Such fluctuations affect the seismic impedance contrasts leading to the anomalous reflectors in the corridor stacks. Two such reflectors are labeled as \#2 and \#3 in the corridor stacks (Fig. 8c). These reflectors are questionable as they do not align with any of the reflectors in the synthetic seismograms. One explanation is that these reflectors are artifacts in the stack as they are located close to depths that experience both borehole caving and change in borehole diameter between 1,654 and 1,740 m depth (Chan 2013), as seen in the caliper logs in Fig. 7. These affect the quality of the data sets, which also lead to the inaccurate travel times recorded at these receiver levels.

\section{Tube waves}

Tube waves are Stoneley waves that occur at the low frequencies of seismic data and are generated when the fluid in the well is displaced by a seismic source such as ground roll. From the perspective of seismic imaging, they are considered as one of the most damaging types of noise in a VSP because they are a strong coherent noise mode that repeats itself in every seismic shot (e.g., Hardage 1981, 2000; Greenwood et al. 2012) and as such cannot be removed by simple stacking of traces. In a cased borehole, a tube wave is an interface wave when the Rayleigh wave propagates down the borehole along the interface between the fluid in the borehole and the borehole wall. In the open hole sections, the tube waves are influenced by changes in the borehole diameter (e.g., variations in casing, borehole caving, fractures), casing conditions, cement bonding, or contrasts in acoustic impedance (Hardage 2000). In the context here, the tube waves are most useful as a tool to assist in the delineation of permeable fracture zones (e.g., Huang and Hunter 1984; Beydoun et al. 1985; Toksöz et al. 1992; Bakku et al. 2013).

Tube waves dominate both the downgoing and upgoing events at later times in the basement section of the zerooffset VSP. They can be created by compressional body waves when they encounter strong impedance contrasts within a borehole, such as casing point, change in borehole diameter, or permeable fractures. A total of three major sets of tube waves intersecting the borehole are interpreted from the processed section at 1,010 $\pm 5,1,402 \pm 20$, and $1,635 \pm 5 \mathrm{~m}$. The larger error at $1,402 \mathrm{~m}$ depth is due to the relatively lower signal-to-noise ratio compared to other 
depths in the open hole section, which greatly mask the origin of the tube waves (Fig. 6). Multiple-scattered tube waves are observed at the same depth from the numerous downgoing events in the profile. These downgoing tube waves can be traced upward to determine their points of origin as labeled in Fig. 6. The amplitude for the first downgoing tube waves fade near the surface, but the linear slope of this wave is traced upward toward the first casing shoe depth at approximately $94 \mathrm{~m}$. The exact origins of these downgoing waves are unknown. One likely explanation is the ground roll impinging on the well head and propagating downward into the subsurface (e.g., Li and Richwalski 1996). An alternative explanation is the presence of an air wave that provides a pressure pulse into the open borehole.

The relatively stronger sets (higher amplitude) of upgoing tube waves are at approximately 1,010 and 1,635 m depth. These are close to the depth levels in which there are impedance contrasts at 1,006 and 1,654 $\mathrm{m}$, which suggests that small-scale fluctuations in the borehole diameter (22-60 mm) are sufficient to generate tube waves in borehole seismic data (Fig. 2). The casing shoe at $1,006 \mathrm{~m}$ corresponds to a change in borehole impedance and a change in diameter at the end of the casing shoe, which creates a tube wave as a propagating body wave.

One useful application of tube waves is fracture zone analysis (e.g., Li et al. 1994). The high-frequency tube waves have greater resolution than body waves, which make it possible to detect thin layers including fracture zones (Mjelde 1992). At 1,402 m depth, this set of tube waves does not correlate to any change in borehole diameter but is related to the presence of the fracture zones. This zone is close to the low-resistivity fracture zone that was previously identified in the geophysical well logs and the dipping seismic reflector that may intersect the borehole (Chan 2013). As tube wave energy can be attenuated by fluid interaction between the borehole and the formation rock due to the presence of permeable fractures, this provides a reasonable explanation to the lower amplitudes of this set of upgoing tube waves compared to the tube waves discussed in the previous paragraph.

The final set of upgoing tube waves is identified in Fig. 5 with its depth estimated by extrapolating the downgoing and upgoing tube waves down the section. Under the assumption that the average velocity is constant in the projected section of the borehole, this reflector originates from the bottom of the borehole as a result of a seismic signal below the bottom of the borehole being converted to tube waves.

\section{Conclusions}

A zero-offset vertical seismic profile was acquired in a deep borehole near Fort McMurray, Alberta, Canada, as part of the regional geothermal resource investigation. The main intention of this study is to utilize the availability of a deep borehole for the subsurface characterization of the Precambrian basement rocks. The dense recording $(2.5 \mathrm{~m})$ of seismic traces of the zero-offset VSP data allows for increased spatial resolution in the study borehole compared to the surface seismic reflection profiles. The processed VSP data and interpretations are discussed with a focus on the output velocity profile, corridor stacks, and tube wave analysis.

The velocity profile calculated from the first arrival picks generates a 1D model of the in situ interval seismic velocity. It is useful toward the velocity analysis of normal moveout correction for processing the seismic reflection data. Localized increases in velocity correlate with density peaks and are possibly related to the changes in rock composition and textures of the metamorphic basement rocks. $\mathrm{P}$-wave velocity ranges between 5,500 and $6,500 \mathrm{~m} / \mathrm{s}$. However, a direct comparison of P-wave velocity between the VSP and sonic log data is difficult due to the frequency dispersion effect.

The poor coupling between geophones and the borehole wall contributes to the lower quality of the data in the open hole section. Despite multiple recordings of seismic shots at each depth for common depth stacking, the signalto-noise ratio of the traces remains poor in the open hole section of the borehole seismic data. Initial interpretation of the corridor stacks was limited to the sedimentary successions behind the cased section of the borehole. This facilitates the horizon interpretation in the surface seismic reflection data and allows for the direct correlation of data in both time and depth. In the metamorphic basement section, the synthetic seismograms generated from the sonic logs help to identify the true reflectors in the corridor stacks generated from the VSP data. They serve to identify the primary reflectors in the borehole seismic data when the signal-to-noise ratio of the data is affected by the condition of the borehole. Interpretations focused on the depth section with overlapping data between 1,006 and 1,800 m. Reflectors are present at two depths in both data sets at 1,408 and $1,695 \mathrm{~m}$, which can then be related back to the seismic reflection profiles to improve the subsurface interpretation of the basement rocks.

Analysis of the upgoing tube waves reveals the effect of borehole diameter changes and the fracture zone that was also interpreted in the available geophysical logs. Tube wave identification is also used to estimate the depth of reflectors originated from beneath the bottom of the borehole by method of extrapolation. One set of tube waves is found to intersect the fracture zone in the borehole corresponding to the results from the geophysical logging. Furthermore, the tube wave close to the bottom of the VSP section appears to be generated by a seismic signal from below the bottom of the borehole. 
With the lack of cores available from this deep borehole, the geological reasoning of the seismic reflectors and changes in interval velocities are unverified. Geophysical logging, borehole, and surface seismic data have all been acquired in the deep borehole to allow for an integrated study of the Precambrian basement rocks. This is still an ongoing project, and the sonic scanner ${ }^{\mathrm{TM}}$ data acquired in late 2013 will be further analyzed to assist with the understanding of seismic anisotropy in the metamorphic Canadian Shield.

Acknowledgments The authors would like to thank the operational support group of the International Continental Scientific Drilling Program (ICDP-OSG) for their assistance in downhole logging, members of the Experimental Geophysics Group (EGG) for their assistance in data acquisition, and Greg Nieuwenhuis for organizing the field logistics for data acquisition. We would also like to thank our reviewers for their insightful and detailed feedback for this paper. This research was sponsored by funding from the geothermal theme of the HelmholtzAlberta Initiative (HAI).

Open Access This article is distributed under the terms of the Creative Commons Attribution License which permits any use, distribution, and reproduction in any medium, provided the original author(s) and the source are credited.

\section{References}

Al-Ali ZA, Al-Buali MH, AlRuwaili S, Ma SM, Marsala AF (2009) Looking deep into the reservoir. Oilfield Rev 21(2):38-47

Bakku SK, Fehler M, Burns D (2013) Fracture compliance estimation using borehole tube waves. Geophysics 78:D249-D260. doi:10.1 190/geo2012-0521.1

Bartetzko A, Delius H, Pechnig R (2005) Effect of compositional and structural variations on $\log$ responses of igneous and metamorphic rocks. I: mafic rocks. In: Petrophysical properties of crystalline rocks. Special Publication edn. Geological Society, London, pp 255-278

Beydoun WB, Cheng CH, Toksöz MN (1985) Detection of open fractures with vertical seismic profiling. J Geophys Res 90:4557. doi: 10.1029/JB090iB06p04557

Birch F (1952) Elasticity and constitution of the Earth's interior. J Geophys Res 57:227-286. doi:10.1029/JZ057i002p00227

Bouzidi Y, Schmitt DR, Burwash RA, Kanasewich ER (2002) Depth migration of deep seismic reflection profiles: crustal thickness variations in Alberta. Can J Earth Sci 39:331-350. doi:10.1139/ e01-080

Burton A, Lines L (1996) VSP detection of interbed multiples using inside-outside corridor stacking. Can J Explor Geophys 32(2):113-120

Burwash RA (1979) Uranium and thorium in the Precambrian basement of western Canada. II. Petrologic and tectonic controls. Can J Earth Sci 16:472-483. doi:10.1139/e79-043

Burwash RA, Culbert RR (1976) Multivariate geochemical and mineral patterns in the Precambrian basement of western Canada. Can J Earth Sci 13:1-18. doi:10.1139/e76-001

Burwash RA, Cumming GL (1976) Uranium and thorium in the Precambrian basement of western Canada. I. Abundance and distribution. Can J Earth Sci 13:284-293. doi:10.1139/e76-030

Burwash RA, McGregor CR, Wilson JA (1994) Precambrian basement beneath the Western Canada sedimentary basin. In: Mossop
GD, Shetsen I (eds) Geological atlas of the Western Canada sedimentary basin. Canadian Society of Petroleum Geologists and Alberta Research Council, Calgary, pp 49-56

Burwash RA, Krupicka J, Wijbrans JR (2000) Metamorphic evolution of the Precambrian basement of Alberta. Can Mineral 38:423434. doi:10.2113/gscanmin.38.2.423

Cameli GM, Batini F, Dini I, Lee JM, Gibson RL, Toksoz MN (1995) Seismic delineation of a geothermal reservoir in the Monteverdi area from VSP data. In: Proceedings of the WGC, pp 821-826

Carr BJ et al (1996) Vertical seismic profile results from the Kola Superdeep Borehole, Russia. Tectonophysics 264:295-307. doi:10.1016/s0040-1951(96)00133-3

Chan J (2013) Subsurface geophysical characterization of the crystalline Canadian Shield in northeastern Alberta: implications for geothermal development. M. Sc., University of Alberta, Edmonton, Alberta

Chan J, Schmitt DR (2014) Elastic anisotropy of a metamorphic rock sample of the Canadian Shield in northeastern Alberta. Rock Mech Rock Eng 1-17. doi:10.1007/s00603-014-0664-z

Clowes RM (2010) Initiation, development, and benefits of Lithoprobe: shaping the direction of Earth science research in Canada and beyond. Can J Earth Sci 47:291-314. doi:10.1139/ e09-074

Cosma C, Heikkinen P, Keskinen J, Enescu N (2001) VSP in crystalline rocks: from downhole velocity profiling to 3-D fracture mapping. Int J Rock Mech Min Sci 38:843-850. doi:10.1016/ s1365-1609(01)00049-1

Drury MJ (1985) Heat flow and heat generation in the Churchill Province of the Canadian Shield, and their palaeotectonic significance. Tectonophysics 115:25-44. doi:10.1016/0040-1951(85)90097-6

Drury MJ (1988) Tectonothermics of the North American great plains basement. Tectonophysics 148:299-307. doi:10.1016/0040-1951(88)90136-9

Duo X (2011) Surface and borehole seismic images at the International Continental Drilling Program Outokumpu borehole: implications for reflectivity of the crystalline crust. M. Sc., University of Alberta, Edmonton, Alberta

Eaton D, Guest S, Milkereit B, Bleeker W, Crick D, Schmitt DR, Salisbury M (1996) Seismic imaging of massive sulfide deposits: part III. Borehole seismic imaging of near-vertical structures. Econ Geol Bull Soc Econ Geol 91:835-840

Emmermann R, Lauterjung J (1997) The German Continental Deep Drilling Program KTB: overview and major results. J Geophys Res 102(B8):18179-18201. doi:10.1029/96jb03945

Emmermann R, Wohlenberg J (eds) (1989) The Germany Continental Deep Drilling Program. Springer, Berlin. doi:10.1007/978-3642-74588-1

Ganchin YV, Smithson SB, Morozov IB, Smythe DK, Garipov VZ, Karaev NA, Kristofferson Y (1998) Seismic studies around the Kola Superdeep Borehole, Russia. Tectonophysics 288:1-16. doi:10.1016/s0040-1951(97)00280-1

Goff SP, Godfrey JD, Holland JG (1986) Petrology and geochemistry of the Canadian Shield of Northeastern Alberta. Alberta Res Counc Bull 51:65. http://www.ags.gov.ab.ca/publications/abstracts/ BUL_051.html

Greenwood A, Dupuis CJ, Urosevic M, Kepic A (2012) Hydrophone VSP surveys in hard rock. Geophysics 77:WC223-WC234. doi: 10.1190/geo2011-0490.1

Gritto R, Daley TM, Majer EL (2003) Estimating subsurface topography from surface-to-borehole seismic studies at the Rye Patch geothermal reservoir, Nevada, USA. Geothermics 32:275-295. doi:10.1016/S0375-6505(03)00022-1

Hajnal Z, Ansdell KM, Ashton KE (2005) Introduction to special issue of Canadian journal of earth sciences: the Trans-Hudson Orogen transect of lithoprobe. Can J Earth Sci 42:379-383. doi:10.1139/e05-053 
Hardage BA (1981) An examination of tube wave noise in vertical seismic profiling data. Geophysics 46:892-903. doi:10.1190/1.144122

Hardage BA (1985) Vertical seismic profiling. In: Handbook of geophysical exploration series, 2nd edn, vol 14. Geophysical Press, London

Hardage BA (2000) Vertical seismic profiling: principles. In: Handbook of geophysical exploration, 3rd updated and revised edn, vol 14. Pergamon, Amsterdam

Harjes HP et al (1997) Origin and nature of crystal reflections: results from integrated seismic measurements at the KTB superdeep drilling site. J Geophys Res 102:18267. doi:10.1029/96jb03801

Heinonen S, Kukkonen IT, Heikkinen P, Schmitt DR (2011) High resolution reflection seismics integrated with deep borehole data in Outokumpu, Finland. In: Kukkonen IT (ed) Outokumpu deep drilling project 2003-2010, vol Special Paper 51. Geological Survey of Finland, Espoo, Finland, pp 105-118

Hope J, Eaton DW, Ross GM (1999) Lithoprobe seismic transect of the Alberta Basin: compilation and overview. Bull Can Pet Geol 47:331-345

Huang CF, Hunter JA (1984) The tube-wave method of estimating in situ rock fracture permeability in fluid-filled boreholes. Geoexploration 22:245-259. doi:10.1016/0016-7142(84)90015-2

Ji S, Xu Z (2009) Drilling deep into the ultrahigh pressure (UHP) metamorphic terrane. Tectonophysics 475:201-203. doi:10.1016/j.tecto.2009.04.007

Kanasewich ER, Cumming GL (1965) Near-vertical-incidence seismic reflections from the "Conrad" discontinuity. J Geophys Res 70:3441-3446. doi:10.1029/JZ070i014p03441

Kukkonen IT (ed) (2011), Outokumpu deep drilling project 20032010, Special Paper 51. Geological Survey of Finland, Espoo, Finland, p 252

Kukkonen IT, Heinonen S, Heikkinen P, Sorjonen-Ward P (2012) Delineating ophiolite-derived host rocks of massive sulfide $\mathrm{Cu}-$ Co-Zn deposits with 2D high-resolution seismic reflection data in Outokumpu, Finland. Geophysics 77:WC213-WC222. doi:10. 1190/geo2012-0029.1

Langenberg CW, Nielsen PA (1982) Polyphase metamorphism in the Canadian Shield of northeastern Alberta. Alberta Res Counc Bull 42:80. http://www.ags.gov.ab.ca/publications/abstracts/BUL_042. html

Li XP, Richwalski S (1996) Seismic attenuation and velocities of Pand S-waves in the German KTB area. J Appl Geophys 36:67-76. doi:10.1016/S0926-9851(96)00036-5

Li YD, Rabbel W, Wang R (1994) Investigation of permeable fracture-zones by tube-wave analysis. Geophys J Int 116:739-753. doi:10.1111/j.1365-246X.1994.tb03294.x

Lorenz H, Gee D, Juhlin C (2011) The Scandinavian Caledonides-scientific drilling at mid-crustal level in a Palaeozoic major collisional orogen. Sci Drill 11:60-63. doi:10.2204/iodp.sd.11.10.2011

Luo MA, Pan HP (2010) Well logging responses of UHP metamorphic rocks from CCSD main hole in Sulu Terrane, Eastern Central China. J Earth Sci China 21:347-357. doi:10.1007/ s12583-010-0098-9

Lüschen E, Bram K, Söllner W, Sobolev S (1996) Nature of seismic reflections and velocities from VSP-experiments and borehole measurements at the KTB deep drilling site in southeast Germany. Tectonophysics 264:309-326. doi:10.1016/ s0040-1951(96)00134-5

Luthi SM (2005) Fractured reservoir analysis using modern geophysical well techniques: application to basement reservoirs in Vietnam. In: Harvey PK, Brewer TS, Pezard PA, Petrov VA (eds) Petrophysical properties of crystalline rocks. Special Publication 240, vol 240(1). Geological Society, London, pp 95-106

Lyatsky H, Pană DI (2003) Catalogue of selected regional gravity and magnetic maps of Northern Alberta. EUB/AGS Special Report 56:40. http://www.ags.gov.ab.ca/publications/abstracts/SPE_056.html
Majorowicz J et al (2014) The first deep heat flow determination in crystalline basement rocks beneath the Western Canadian sedimentary basin. Geophys J Int 197:731-747. doi:10.1093/gji/ggu065

McDonough MR, McNicoll VJ, Schetselaar EM, Grover TW (2000) Geochronological and kinematic constraints on crustal shortening and escape in a two-sided oblique-slip collisional and magmatic orogen, Paleoproterozoic Taltson magmatic zone, northeastern Alberta. Can J Earth Sci 37:1549-1573. doi:10.1139/ cjes-37-11-1549

Melosh G, Cumming W, Casteel J, Niggemann K, Fairbank B (2010) Seismic reflection data and conceptual models for geothermal development in Nevada. In: Proceedings world geothermal congress, Bali, Indonesia, p 6

Miao X, Moon WM, Milkereit B, Mwenifumbo CJ (1994) Three component vertical seismic profiling (VSP) experiment in the Sudbury Basin. Geophys Res Lett 21:939-942. doi:10.1029/93g102246

Mjelde R (1992) Reflection and polarization of tube waves as seen in Vsp data. Geophys Prospect 40:605-617. doi:10.1111/j.13652478.1992.tb00544.x

Mwenifumbo CJ, Elliott BE, Jefferson CW, Bernius GR, Pflug KA (2004) Physical rock properties from the Athabasca group: designing geophysical exploration models for unconformity uranium deposits. J Appl Geophys 55:117-135. doi:10.1016/j.jappgeo. 2003.06.008

Nakagome O, Uchida T, Horikoshi T (1998) Seismic reflection and VSP in the Kakkonda geothermal field, Japan: fractured reservoir characterization. Geothermics 27:535-552. doi:10.1016/S03756505(98)00032-7

Okaya D (2004) P wave material anisotropy of a tectono-metamorphic terrane: an active source seismic experiment at the KTB super-deep drill hole, southeast Germany. Geophys Res Lett 31. doi:10.1029/2004g1020855

Pană DI (2003) Precambrian basement of the Western Canada Sedimentary Basin in Northern Alberta. EUB/AGS Earth sciences report 2002-2002. Alberta Geological Survey. http://www.ags. gov.ab.ca/publications/abstracts/ESR_2002_02.html

Pavlenkova NI (1992) The Kola superdeep drillhole and the nature of seismic boundaries. Terra Nova 4:117-123. doi:10.1111/j.1365-3121. 1992.tb00456.x

Pilkington M, Miles WF, Ross GM, Roest WR (2000) Potentialfield signatures of buried Precambrian basement in the Western Canada Sedimentary Basin. Can J Earth Sci 37:1453-1471. doi:10.1139/E00-020

Place J, Sausse J, Marthelot JM, Diraison M, Geraud Y, Naville C (2011) 3-D mapping of permeable structures affecting a deep granite basement using isotropic 3C VSP data. Geophys J Int 186:245-263. doi:10.1111/j.1365-246X.2011.05012.x

Rabbel W et al (2004) Superdeep vertical seismic profiling at the KTB deep drill hole (Germany): seismic close-up view of a major thrust zone down to $8.5 \mathrm{~km}$ depth. J Geophys Res 109. doi:10.10 29/2004jb002975

Rector JW (1988) Acquisition and preliminary analysis of oriented multi-component multioffset VSP data: DOSECC Cajon Pass Deep Scientific Drillhole. Geophys Res Lett 15:1061-1064. doi: 10.1029/GL015i009p01061

Ross G (2000) Introduction to special issue of Canadian Journal of Earth Sciences: the Alberta Basement Transect of Lithoprobe. Can J Earth Sci 37:1447-1452. doi:10.1139/E00-097

Ross GM (2002) Evolution of Precambrian continental lithosphere in Western Canada: results from Lithoprobe studies in Alberta and beyond. Can J Earth Sci 39:413-437. doi:10.1139/E02-012

Ross GM, Eaton DW (1999) Basement reactivation in the Alberta Basin: observational constraints and mechanical rationale. Bull Can Pet Geol 47(4):391-411

Ross GM, Parrish RR, Villeneuve ME, Bowring SA (1991) Geophysics and geochronology of the crystalline basement of the 
Alberta Basin, Western Canada. Can J Earth Sci 28:512-522. doi:10.1139/E91-045

Sams MS, Neep JP, Worthington MH, King MS (1997) The measurement of velocity dispersion and frequency-dependent intrinsic attenuation in sedimentary rocks. Geophysics 62:1456-1464. doi:10.1190/1.1444249

Schijns H, Schmitt DR, Heikkinen PJ, Kukkonen IT (2012) Seismic anisotropy in the crystalline upper crust: observations and modelling from the Outokumpu scientific borehole, Finland. Geophys J Int 189:541-553. doi:10.1111/j.1365-246X.2012.05358.x

Schmitt DR, Milkereit B, Karp T, Scholz C, Danuor S, Meillieux D, Welz M (2007) In situ seismic measurements in borehole LB-08A in the Bosumtwi impact structure, Ghana: preliminary interpretation. Meteorit Planet Sci 42:755-768. doi:10.1111/j.1945-5100.2007.tb01072.x

Schutter SR (2003) Hydrocarbon occurrence and exploration in and around igneous rocks. Geol Soc Lond Spec Publ 214:7-33. doi: 10.1144/Gsl.Sp.2003.214.01.02
Sheriff RE (2002) Encyclopedic dictionary of applied geophysics. In: Geophysical reference series, 4th edn, vol 13. Society of Exploration Geophysicists, Tulsa, Oklahoma

Stewart RR (1985) Median filtering: review and a new F/K analogue design. J Can Soc Explor Geophys 21(1):54-63

Stewart RR (2001) VSP: An in-depth seismic understanding. CSEG Recorder :79-83

Toksöz MN, Cheng CH, Cicerone RD (1992) Chapter 16 fracture detection and characterization from hydrophone vertical seismic profiling data. Int Geophys 51:389-414. doi:10.1016/s0074-6142(08)62831-4

Vernik L, Hickman S, Lockner D, Rusanov M (1994) Ultrasonic velocities in cores from the Kola superdeep well and the nature of subhorizontal seismic reflections. J Geophys Res 99:24209. doi:10.1029/94jb01236

Walsh NJ (2013) Geochemistry and geochronology of the Precambrian basement domains in the vicinity of Fort McMurray, Alberta: a geothermal perspective. M.Sc., University of Alberta, Edmonton, Alberta 